\title{
UIMC1 Gene
}

National Cancer Institute

\section{Source}

National Cancer Institute. UIMC1 Gene. NCI Thesaurus. Code C124098.

This gene is involved in ubiquitin binding and DNA damage responses. 